\title{
Prevention of Intraoperative Hypothermia in Laparoscopy by the Use of Body-Temperature and Humidified $\mathrm{CO}_{2}$ : a Pilot Study \\ Prävention intraoperativer Hypothermie in der Laparoskopie durch die Anwendung von körperwarmem und humidifiziertem $\mathrm{CO}_{2}$ : eine Pilotstudie
}

\section{(c) (1) $\ominus$}

\section{Authors}

Julia Wittenborn ${ }^{1}$, Annika Clausen ${ }^{1}$, Felix Zeppernick ${ }^{1,2}$, Elmar Stickeler ${ }^{1}$, Ivo Meinhold-Heerlein ${ }^{1,2}$

Affiliations

1 Klinik für Gynäkologie und Geburtsmedizin, Uniklinik RWTH Aachen, Aachen, Germany

2 Zentrum für Frauenheilkunde und Geburtshilfe, Justus-Liebig-Universität Gießen, Gießen, Germany

Key words

laparoscopy, intraoperative hypothermia, HumiGard ${ }^{\circledR}$, pneumoperitoneum

\section{Schlüsselwörter \\ Laparoskopie, intraoperative Hypothermie, Humigard ${ }^{\circledR}$, Pneumoperitoneum}

$\begin{array}{lr}\text { received } & 18.9 .2018 \\ \text { revised } & 28.3 .2019 \\ \text { accepted } & 30.4 .2019\end{array}$

Bibliography

DOI https://doi.org/10.1055/a-0903-2638

Geburtsh Frauenheilk 2019; 79: 969-975 @ Georg Thieme

Verlag KG Stuttgart · New York | ISSN 0016-5751

Correspondence

Dr. med. Julia Wittenborn

Klinik für Gynäkologie und Geburtsmedizin, Uniklinik RWTH Aachen

Pauwelsstraße 30, 52074 Aachen, Germany

juwittenborn@ukaachen.de

Correspondence

Prof. Dr. Ivo Meinhold-Heerlein

Zentrum für Frauenheilkunde und Geburtshilfe,

Justus-Liebig-Universität Gießen

Klinikstraße 33, 35392 Gießen, Germany

ivo.meinhold-heerlein@gyn.med.uni-giessen.de

Deutsche Version unter:

https://doi.org/10.1055/a-0903-2638

\section{ABSTRACT}

Introduction Hypothermia is defined as a decrease in body core temperature to below $36^{\circ} \mathrm{C}$. If intraoperative heat-preserving measures are omitted, a patient's temperature will fall by $1-2^{\circ} \mathrm{C}$. Even mild forms of intraoperative hypothermia can lead to a marked increase in morbidity and mortality. The temperature of the insufflation gas is usually disregarded in the treatment and prevention of hypothermia. This study was conducted to investigate the effect of body-temperature and humidified $\mathrm{CO}_{2}$ on the intraoperative temperature profile and avoidance of hypothermia in laparoscopic surgery.

Material and Methods In this retrospective, non-randomised case control study, 110 patients whose planned operation lasted at least 60 minutes were identified from 376 patients by means of an algorithm. Dry (20\% humidity) $\mathrm{CO}_{2}$ at room temperature was insufflated in 51 patients (control group). 59 patients were insufflated with humidified ( $98 \%$ humidity) $\mathrm{CO}_{2}$ at body temperature $\left(37^{\circ} \mathrm{C}\right.$ ) (study group). These conditions were achieved with the HumiGard MR860 Surgical Humidification System (Fisher \& Paykel Healthcare Limited, Auckland, New Zealand). The intraoperative temperature profile was evaluated by measurements every 10 minutes. Statistical analysis was performed with IBM $^{\circledR}$ SPSS $^{\circledR}$ Statistics 23.0.0.

Results The intraoperative temperature in the control group fell steadily, while a continuous rise in temperature was observed in the study group. Warming was demonstrated in the study group with a start-end temperature difference of $0.09^{\circ} \mathrm{C}$, which differed significantly from the control group, in which it was $-0.09^{\circ} \mathrm{C}(p=0.011)$. The middle-end difference of $0.11^{\circ} \mathrm{C}$ showed even higher significance in favour of the warmed gas $(p=0.003)$. The rate of hypothermia at the start of the operation fell from 50 to $36 \%$ in the study group and increased from 36 to $42 \%$ in the control group.

Conclusion These results show that the use of body-temperature and humidified insufflation gas for laparoscopy can help to prevent intraoperative hypothermia. 


\section{ZUSAMMENFASSUNG}

Einleitung Hypothermie wird definiert als ein Absinken der Körperkerntemperatur auf unter $36^{\circ} \mathrm{C}$. Wenn intraoperativ auf den Einsatz wärmeerhaltender Maßnahmen verzichtet wird, sinkt die Temperatur eines Patienten um $1-2^{\circ} \mathrm{C}$. Bereits milde Formen intraoperativer Hypothermie können zu einer deutlichen Erhöhung der Morbidität und Mortalität führen. Bei der Behandlung und Prävention von Hypothermie wird die Temperatur des Insufflationsgases meist außer Acht gelassen. Diese Studie wurde durchgeführt, um die Auswirkung von körperwarmem und humidifiziertem $\mathrm{CO}_{2}$ auf den intraoperativen Temperaturverlauf und die Vermeidung einer Hypothermie bei laparoskopischen Operationen zu untersuchen.

Material und Methoden Im Rahmen der retrospektiven nicht randomisierten Fallkontrollstudie wurden mittels eines Algorithmus aus 376 Patientinnen 110 Patientinnen identifiziert, die eine geplante Operationsdauer von mindestens 60 Minuten aufwiesen. Bei 51 Patientinnen wurde trockenes (20\% Luftfeuchte) und raumwarmes $\mathrm{CO}_{2}$ insuffliert (Kontrollgruppe). Bei 59 Patientinnen wurde humidifiziertes (98\% Luftfeuchte) und gleichzeitig körperwarmes $\left(37^{\circ} \mathrm{C}\right) \mathrm{CO}_{2}$ insuffliert
(Versuchsgruppe). Diese Bedingungen wurden mit dem HumiGard MR860 Surgical Humidifaction System (Fisher \& Paykel Healthcare Limited, Auckland, New Zealand) erreicht. Der intraoperative Temperaturverlauf wurde durch Messungen alle 10 Minuten evaluiert. Die statistische Analyse erfolgte mit IBM ${ }^{\circledR}$ SPSS $^{\circledR}$ Statistics 23.0.0.

Ergebnisse Die Temperatur in der Kontrollgruppe sank intraoperativ stetig, während in der Versuchsgruppe ein kontinuierlicher Temperaturanstieg beobachtet werden konnte. Für die Start-End-Differenz der Temperatur konnte in der Versuchsgruppe eine Erwärmung um $0,09^{\circ} \mathrm{C}$ gezeigt werden, die sich signifikant von der Kontrollgruppe mit $-0,09^{\circ} \mathrm{C}$ $(p=0,011)$ unterschied. Die Mittel-End-Differenz ergab mit $0,11^{\circ} \mathrm{C}$ eine noch höhere Signifikanz zugunsten des erwärmten Gases $(p=0,003)$. Die Rate der Hypothermien zu Beginn der Operation sank bei der Versuchsgruppe von 50 auf 36\%; sie stieg bei der Kontrollgruppe von 36 auf $42 \%$ an.

Schlussfolgerung Die vorliegenden Ergebnisse zeigen, dass die Verwendung von körperwarmem und humidifiziertem Insufflationsgas bei der Laparoskopie zur Prävention introperativer Hypothermien beitragen kann.

\section{Introduction}

Intraoperative hypothermia is defined as a decrease in core body temperature to below $36^{\circ} \mathrm{C}$. Without the use of heat-preserving measures, the temperature of most patients falls by $1-2^{\circ} \mathrm{C}$ during an operation as their intrinsic thermoregulation switches off [1]. Due to the effect of general anaesthesia, the body is no longer able to counteract the reduction in temperature by shivering or vasoconstriction [1]. In addition, the room temperature is often low, and cooling takes place across wound surfaces. Skin incisions for laparoscopy are much smaller than those of open surgical procedures, but the entire internal abdominal body surface comes in contact with the cold and dry insufflated gas $\left(\mathrm{CO}_{2}\right)$. The temperature drop during laparoscopic procedures therefore does not differ essentially from that seen during open surgery [2,3]. Even mild forms of intraoperative hypothermia can lead to a marked increase in morbidity and mortality. The negative consequences of intraoperative hypothermia have been well researched and include disturbance of blood clotting with increased blood loss and an increased rate of transfusions, myocardial dysfunction, arrhythmias and hypokalaemia. In addition, delayed wound healing and wound infections occur more often, with prolonged hospitalisation as a result [ $4-6]$.

$\mathrm{CO}_{2}$ at room temperature is usually employed in laparoscopic surgery for insufflation of the pneumoperitoneum; it is relatively cold and dry compared with body temperature. This factor is often overlooked when intraoperative hypothermia develops. Evidence from studies conducted in pigs show, however, that the risk of hypothermia can be reduced by the use of warmed and humidified insufflation gas [7-10]. The question is particularly relevant in gynaecology as women in particular tend towards intraoperative hypothermia [11].
The aim of this retrospective case control study was to investigate the effect of humidified $\mathrm{CO}_{2}$ at body temperature on the intraoperative temperature profile in order to demonstrate possible prevention of hypothermia.

\section{Material and Methods}

The retrospective, non-randomised case control study was conducted in the department of gynaecology and obstetrics of RWTH Aachen University Hospital. Patients were allocated to the study or control group using the independent variable "Use of HumiGard ${ }^{\circledR}$ ". All patients in whom HumiGard ${ }^{\circledR}$ had been used during their laparoscopy were assigned to the study group. This system had not been used in the patients in the control group.

\section{Patients}

The study included patients who had undergone operative laparoscopy before 01.05.2011 and after 12.07.2013, as use of HumiGard $^{\circledR}$ in the intervening period could not be traced from the documentation.

The patients selected for the control group were those who had surgery in RWTH Aachen University Hospital after 04.01.2009 but before the HumiGard system was first used (01.05.2011).

The study group comprised patients in whom the use of HumiGard $^{\circledR}$ was documented after 12.07.2013.

A further inclusion criterion was documented use of the $3 \mathrm{M}^{\mathrm{TM}}$ Bair Hugger ${ }^{\mathrm{TM}}$ warming unit (3M, Neuss, Germany), which was part of the standardised heat management of RWTH Aachen University Hospital.

The exclusion criteria were secondary laparotomy, repeated laparoscopies in the same patient, planned operation duration 


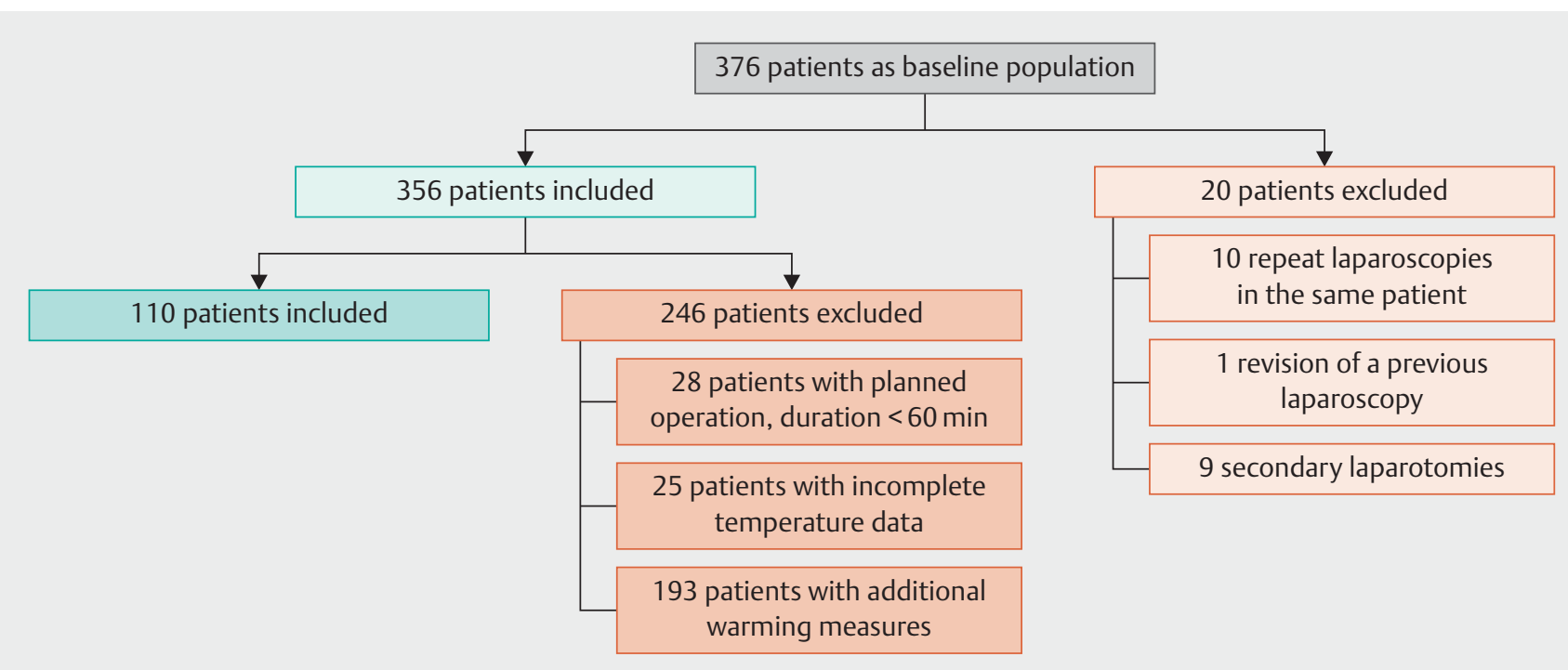

- Fig. 1 Inclusion and exclusion criteria. For the 110 patients included, 33 statistical pairs of twins could be evaluated so 66 patients were used for statistical analysis.

less than 60 minutes, lack of documentation of the intraoperative temperature, additional warming measures in the form of a warming mat, warmed infusions or a combination of the two.

In the control group, the pneumoperitoneum was created and maintained using cold and dry $\mathrm{CO}_{2}$ (room temperature and up to $20 \%$ humidity). In the study group, warm humidified $\mathrm{CO}_{2}$ was used $\left(35 \pm 2{ }^{\circ} \mathrm{C}, 98 \pm 2 \%\right.$ humidity). These parameters were achieved with the HumiGard MR860 Surgical Humidification System ${ }^{\circledR}$ (Fisher \& Paykel Healthcare Limited, Auckland, New Zealand).

The intra-oesophageal temperature was measured intraoperatively every 10 minutes. The first temperature measured after the skin incision was defined as the start temperature. The end temperature was the last measurement before release of the pneumoperitoneum and wound closure.

110 patients were included, 59 in the study group and 51 in the control group. In the control group, no other warming measures were used apart from a warm air blower. There was complete documentation of the intraoperative temperature. Because of the statistical case control matching, the analysis subsequently used only patients for whom a statistical twin could be found ( $\mathrm{n}=33$ per group) ( $\triangleright$ Fig. 1 ).

\section{Statistical analysis}

To eliminate confounding factors from the statistical analysis, the study and control groups were matched. In the case control matching, only the following two criteria showed a Spearman correlation coefficient of $>0.15$ with the key variable "start-end temperature difference" and were therefore used as matching criteria: "operation duration" and "smoker status (yes/no)". Matching was performed by IBM ${ }^{\circledR}$ SPSS $^{\circledR}$ Statistics 23.0.0. The operation duration tolerance range in which the two groups were allowed to differ was set at five minutes. Patients to whom a statistical twin from the other group could not be assigned were excluded from the study. To increase the internal validity, a reduction in the case number from 110 to 66 was therefore accepted.

The temperature data were examined for their statistical significance in an inductive analysis. The case control matching resulted in two dependent samples so the differences in the target variables between the respective twin pairs were examined for a normal distribution. If this was present, a parametric procedure was used (paired t-test). When the target variables were not normally distributed between the matched partners, the Wilcoxon signed-rank test was used. The following characteristics were compared between the two groups as target variables: age at the time of the operation, duration of anaesthesia, number of previous operations, ASA classification, diabetes (yes/no), main diagnosis, intraoperative infusions, hysterectomy operation technique, smoker (yes/no), deeply infiltrating endometriosis (yes/ no) and preparation time until operation.

\section{Results}

\section{Demographic overview}

66 patients were included in the analysis. Because of the case control matching, these were divided equally between the two groups, resulting in a case number of 33 per group. The 66 patients in the study were all women. The mean age was 43.6 years ( \pm 11.9 years), ranging from 20 to 81 years. The median was 42 years.

\section{Operations}

Roughly half of all the operations were hysterectomies (34/66). While 7 patients had laparoscopic supracervical hysterectomy (LASH), total laparoscopic hysterectomy (TLH) was performed 27 times. The average time between start and end of surgery was 124.1 minutes ( \pm 48.9 minutes); the shortest laparoscopy 


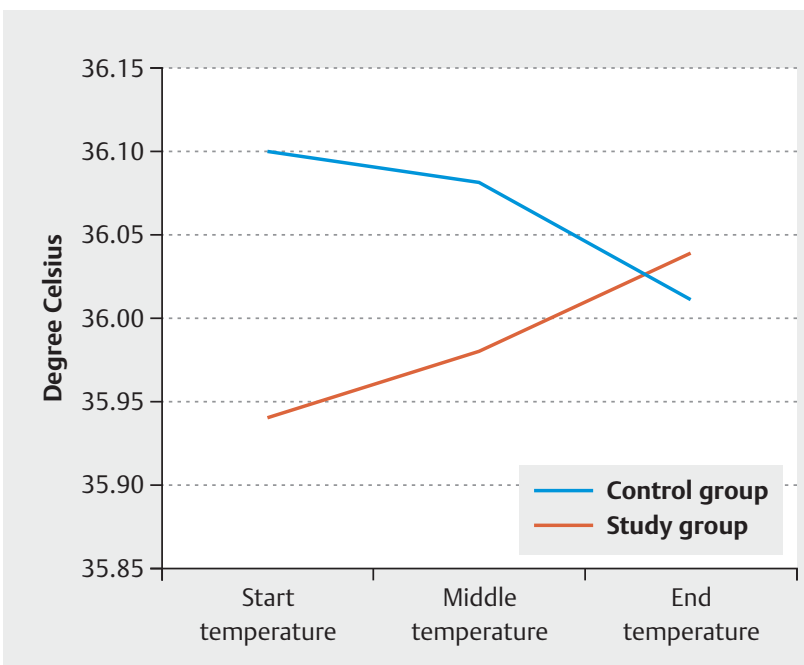

- Fig. 2 Temperature profile of the control and study groups, showing the temperature curves using the start, middle and end of the operation. Measurement was intra-oesophageal. lasted 42 minutes and the longest took 240 minutes. The median was 118.5 minutes.

\section{Patient characteristics}

There was no significant difference between the two groups for the patient characteristics listed in $>$ Table 1 . The study and control groups were therefore comparable with regard to the variables listed in > Table 2.

\section{Temperature analysis}

Comparison of the temperature profile in the two groups showed that the mean value fell steadily in the control group, while it increased in the study group ( $\bullet$ Fig. 2). A test of significance was performed to confirm the opposite temperature profiles ( $\vee$ Table 3 ). Both the start-end difference and, in individual sections, the start-middle and middle-end difference were examined using the paired t-test. The start-end difference was significantly greater in the study group at $0.09^{\circ} \mathrm{C}$ than in the control group, where it was $-0.09^{\circ} \mathrm{C}(p=0.011)$. No significance was found from the start to the middle temperature $(p=0.122)$. In the second period examined, the middle-end difference in the study group was highly significantly above that of the control group at more than $0.11^{\circ} \mathrm{C}$ $(p=0.003)$.

- Table 1 Comparison of the characteristics of the study groups. Group H: study group, group 0: control group

\begin{tabular}{|c|c|c|c|}
\hline Variable & Group 0 & Group H & $\mathrm{p}$ value \\
\hline Age at time of operation (years) & 45 & 42 & $0.313^{1}$ \\
\hline Body Mass Index $\left(\mathrm{kg} / \mathrm{m}^{2}\right)$ & 28 & 25 & $0.079^{1}$ \\
\hline Smoker (yes/no) & 5 & 5 & \\
\hline Diabetes (yes/no) & 3 & 1 & \\
\hline Number of previous operations & 4 & 4 & $0.715^{1}$ \\
\hline \multicolumn{4}{|l|}{ ASA classification (1-5) } \\
\hline$\cdot 1$ & 9 & 18 & \\
\hline .2 & 19 & 12 & \\
\hline .3 & 5 & 3 & \\
\hline \multicolumn{4}{|l|}{ Main diagnostic categories } \\
\hline - Uterine myoma(s) & 11 & 12 & \\
\hline - Endometriosis & 7 & 8 & \\
\hline - Ovarian tumour & 7 & 4 & \\
\hline - Bleeding disorder & 5 & 0 & \\
\hline - Other & 3 & 9 & \\
\hline Deeply infiltrating endometriosis (yes/no) & 2 & $3[32]$ & \\
\hline Operation preparation time (min) & 78 & 74 & $0.476^{1}$ \\
\hline Anaesthesia duration (min) & 178 & 175 & $0.542^{1}$ \\
\hline Incision-suture time (min) & 124 & 124 & $0.867^{2}$ \\
\hline Crystalloid solutions & 1.36 & 1.61 & $0.254^{1}$ \\
\hline Colloid solutions & 0.12 & 0.06 & $0.423^{1}$ \\
\hline
\end{tabular}


- Table 2 Start, middle and end temperature. The measurements were intra-oesophageal. Figures in ${ }^{\circ} \mathrm{C}$.

\begin{tabular}{|l|l|l|l|}
\hline & Start temperature & Middle temperature & End temperature \\
\hline Control group & $36.10( \pm 0.46)$ & $36.07( \pm 0.42)$ & $36.01( \pm 0.40)$ \\
\hline Study group & $35.94( \pm 0.46)$ & $35.98( \pm 0.49)$ & $36.04( \pm 0.49)$ \\
\hline
\end{tabular}

- Table 3 Significance test of temperature differences at the three times: start, middle and end temperature. The start-end, start-middle and middle-end differences were examined by paired t-test. Statistical significance was assumed at $p<0.05$.

\begin{tabular}{|l|l|l|l|l|l|}
\hline & Control group & Study group & t & df & P \\
\hline Start-end difference & -0.09 & 0.09 & 2.70 & 32 & 0.011 \\
\hline Start-middle difference & -0.03 & 0.04 & 1.59 & 32 & 0.122 \\
\hline Middle-end differences & -0.06 & 0.05 & 3.21 & 32 & 0.003 \\
\hline df: degrees of freedom & & & & \\
\end{tabular}

In both groups, the percentage of intraoperative hypothermia at the start and end of the operation was examined. In the study group, the proportion of patients with hypothermia fell markedly from more than 54.22 to $36.36 \%$. By contrast, the proportion of patients with hypothermia increased from 36.36 to $42.42 \%$ in the control group ( $\triangleright$ Table 4).

\section{Discussion}

The decrease in temperature during laparoscopic surgery is due to three causes: the effect of general anaesthesia, environmental factors and the insufflation of dry gas at room temperature. General anaesthesia accounts for most of the decrease as it paralyses the body's intrinsic thermoregulation and reduces metabolic heat production by about $30 \%$. In addition, the room temperature in the operating theatre is often low. The HumiGard ${ }^{\circledR}$ system focuses on the third cause: temperature loss due to insufflation of cold dry gas. This undergoes secondary warming and humidification in the abdominal cavity until it reaches the temperature and humidity of the abdomen and equilibrium is achieved. The heat and also the water content of the peritoneum are diminished continuously during operation. This loss of energy can contribute to the development of hypothermia [7]. Since the peritoneal surface area roughly corresponds to the outer body surface, the importance of attempting to protect intra-abdominal heat becomes clear.

According to Sessler (2016), the core body temperature can provide the most reliable information about a patient's thermal status. The following four sites are suitable for measuring it accurately: the nasopharynx, the distal oesophagus, the ear drum by means of a contact thermometer and the pulmonary artery. The data used in our analysis are based on measurements in the nasopharynx and accordingly deliver valid information on core body temperature [1].

This study showed that use of HumiGard ${ }^{\circledR}$ can prevent a decrease in body temperature. The temperature profile curves ran in the opposite direction to those of the control group. In the lat-
- Table 4 Percentage of hypothermic patients at the three measurement times (start, middle and end temperature). Figures in percent.

\begin{tabular}{|l|l|l|}
\hline Hypothermia (in \%) & Group 0 & Group H \\
\hline Percentage of start temperatures & 36.36 & 54.55 \\
\hline Percentage of middle temperature & 39.39 & 42.42 \\
\hline Percentage of end temperatures & 42.42 & 36.36 \\
\hline
\end{tabular}

ter, there was a drop in body temperature especially in the second half of the operation. The HumiGard ${ }^{\circledR}$ system, which is the only one of its kind on the European market, reduced the rate of hypothermia steadily. By contrast, the rate of hypothermia rose steadily in the course of the operation in the control group. The high preoperative percentage of hypothermia of approximately $55 \%$ in the HumiGard group is noteworthy. Possible reasons are a long interval of time between induction and the actual start of operation, as well as inadequate or omitted prewarming. However, the mean preparation time until operation differ only minimally between the two groups so prewarming appears a more likely explanation. Possible differences in the preoperative procedure at the time of the historical controls may be the reason for the lower percentage of hypothermia at the start of the operation in this group. Effective prewarming results in an intraoperative body temperature that is $0.4^{\circ} \mathrm{C}$ higher compared with controls [1]. However, the HumiGard system reduced hypothermia steadily compared with the control group with a warm air blower only.

In animal studies, in which exclusive warming was investigated primarily, no significant effects were found for avoiding hypothermia. In these animal studies, however, complex heat management (e.g. a warm air blower) was not used. The average incision-to-suture time in these studies was over 120 minutes $[9,12,13]$.

The positive effects of conditioned gas on human temperature metabolism were proclaimed in the 1998 publication by Ott et al. 
on warmed and humidified carbon dioxide. This research team used the Insuflow ${ }^{\circledR}$ system, which is similar to the HumiGard ${ }^{\circledR}$ system and is licensed in the United States. This prospective randomised multi-centre study, which used additional heat management for both groups, showed a temperature difference in favour of Insuflow ${ }^{\circledR}$, which reduced the rate of intraoperative hypothermia [14]. Another recently published randomised study, which additionally used a warm air blower and warm infusions, did not find any significant temperature difference with the use of Humi$\operatorname{Gard}^{\circledR}$. However, this study cannot be used for comparison as the operation times were very short (average of 15 minutes insufflation time [15].

By contrast, we observed the significant temperature differences only in the second half of the operation. In our study, the planned minimum duration of all surgical procedures was 60 minutes.

Studies in humans, which included bariatric patients having laparoscopic reduction of stomach size, did not find any positive effect on intraoperative temperature maintenance $[16,17]$. It should be noted, however, that overweight patients generally tend less to intraoperative hypothermia due to the insulating effect of fat tissue [18].

Consistent with our retrospective case control study, a recent Cochrane analysis in 2016 showed that statistically significantly higher core temperatures were found when warmed and humidified insufflation gas was used. Since the authors criticise the quality of the previous clinical studies, the results will have to be investigated in further studies [19].

Although our study is a retrospective analysis, its strength lies particularly in the precise matching of the patients, the operation duration and the employed warming method. There is therefore high internal validity due to the high comparability of the two groups of patients.

These results show that external body warming by a warm air blower can compensate the initial drop of $1-2^{\circ} \mathrm{C}$ in body temperature due to general anaesthesia. Other options consist of use of warming blankets and also the use of warmed infusions. An adhesive plastic sheet is used more often in open surgery. Ultimately, however, these measures do not affect the peritoneum-lined body cavity. Especially during more protracted laparoscopic operations, additional warming and humidification of the insufflation gas can lead to better maintenance of body temperature and avoidance of hypothermia in the second half of the operation and should therefore be used in addition. The authors of a recently published review also come to this conclusion [20].

Accordingly, there are conflicting publications regarding the question we investigated, sometimes with opposite conclusions. Previous studies are difficult to compare, however, as the patient populations were heterogeneous, the use of additional warming methods differed, the operation times differed markedly, and temperatures were also measured in various ways.

Even though the focus of the present study was on the intraoperative temperature profile and the occurrence of any hypothermia, it should be noted that further beneficial effects are associated with the use of warmed and humidified laparoscopy gas: reduction of postoperative wound infections, postoperative pain and postoperative analgesic consumption have been described.
Because of this, the duration of patient hospitalisation can be reduced, which is of great economic significance $[6,10]$. Avoidance of mesothelial damage due to drying of the peritoneum can prevent the consequent inflammatory reaction with the development of a fibrin matrix, which acts as the basis for adhesions [9].

A precise evaluation of the aforementioned effects, especially from the economic aspect, is still the object of research and must be studied in larger numbers of patients.

\section{Conclusion}

An overall tendency to positive assessment of warming and humidification of insufflation gas is apparent in the literature. By excluding as many confounding factors as possible, the present study delivers the important finding that warming and humidification of the insufflation gas $\mathrm{CO}_{2}$ can make an important contribution to intraoperative temperature maintenance, including avoidance and reduction of intraoperative hypothermia. The small case number due to the strict inclusion and exclusion criteria and the retrospective study design are disadvantages, which will be put into perspective in the prospective randomised clinical TePaLa study (Temperature and Pain in Laparoscopy, ClinicalTrials.gov Identifier: NCT02781194) and other clinical studies.

\section{Acknowledgements}

We thank the operating nursing team at RWTH Aachen University Hospital for the complete documentation of use of HumiGard@).

Parts of this paper were published within the doctoral thesis of Annika Clausen entitled „Auswirkungen der Verwendung von erwärmtem und befeuchtetem CO2 bei laparoskopischen Eingriffen der Gynäkologie auf den intraoperativen Temperaturverlauf - eine retrospektive Analyse“, Medizinische Fakultät, RWTH Aachen, 2019.

\section{Conflict of Interest}

Fisher \& Paykel are supporting the TePaLa study in which Julia Wittenborn and Ivo Meinhold-Heerlein are the principal investigators with a research grant to RWTH Aachen University Hospital. Annika Clausen received assistance with travel costs for a scientific meeting.

References

[1] Sessler DI. Perioperative thermoregulation and heat balance. Lancet 2016; 387: 2655-2664

[2] Berber E, String A, Garland A et al. Intraoperative thermal regulation in patients undergoing laparoscopic vs. open surgical procedures. Surg Endosc 2001; 15: 281-285

[3] Luck A], Moyes D, Maddern G] et al. Core temperature changes during open and laparoscopic colorectal surgery. Surg Endosc 1999; 13: 480483

[4] Frank SM, Fleisher LA, Breslow MJ et al. Perioperative maintenance of normothermia reduces the incidence of morbid cardiac events. A randomized clinical trial. JAMA 1997; 277: 1127-1134

[5] Frank SM, Higgins MS, Fleisher LA et al. Adrenergic, respiratory, and cardiovascular effects of core cooling in humans. Am J Physiol 1997; 272: R557-R562

[6] Melling AC, Ali B, Scott EM et al. Effects of preoperative warming on the incidence of wound infection after clean surgery: a randomised controlled trial. Lancet 2001; 358: 876-880 
[7] Bessell JR, Karatassas A, Patterson JR et al. Hypothermia induced by laparoscopic insufflation. A randomized study in a pig model. Surg Endosc 1995; 9: 791-796

[8] Bessell JR, Ludbrook G, Millard SH et al. Humidified gas prevents hypothermia induced by laparoscopic insufflation: a randomized controlled study in a pig model. Surg Endosc 1999; 13: 101-105

[9] Hazebroek E], Schreve MA, Visser P et al. Impact of temperature and humidity of carbon dioxide pneumoperitoneum on body temperature and peritoneal morphology. J Laparoendosc Adv Surg Tech A 2002; 12: 355364

[10] Peng $Y$, Zheng $M, Y e ~ Q$ et al. Heated and humidified $\mathrm{CO}_{2}$ prevents hypothermia, peritoneal injury, and intra-abdominal adhesions during prolonged laparoscopic insufflations. J Surg Res 2009; 151: 40-47

[11] Lopez M, Sessler DI, Walter K et al. Rate and gender dependence of the sweating, vasoconstriction, and shivering thresholds in humans. Anesthesiology 1994; 80: 780-788

[12] Noll E, Schaeffer R, Joshi $G$ et al. Heat loss during carbon dioxide insufflation: comparison of a nebulization based humidification device with a humidification and heating system. Surg Endosc 2012; 26: 3622-3625

[13] Margulis V, Matsumoto ED, Tunc L et al. Effect of warmed, humidified insufflation gas and anti-inflammatory agents on cytokine response to laparoscopic nephrectomy: porcine model. J Urol 2005; 174: 1452-1456
[14] Ott DE, Reich H, Love B et al. Reduction of laparoscopic-induced hypothermia, postoperative pain and recovery room length of stay by preconditioning gas with the Insuflow device: a prospective randomized controlled multi-center study. JSLS 1998; 2: 321-329

[15] Herrmann A, De Wilde RL. Insufflation with Humidified and Heated Carbon Dioxide in Short-Term Laparoscopy: A Double-Blinded Randomized Controlled Trial. Biomed Res Int 2015. doi:10.1155/2015/412618

[16] Champion JK, Williams M. Prospective randomized trial of heated humidified versus cold dry carbon dioxide insufflation during laparoscopic gastric bypass. Surg Obes Relat Dis 2006; 2: 445-449; discussion 449450

[17] Davis SS, Mikami DJ, Newlin M et al. Heating and humidifying of carbon dioxide during pneumoperitoneum is not indicated: a prospective randomized trial. Surg Endosc 2006; 20: 153-158

[18] Matsukawa T, Kurz A, Sessler DI et al. Propofol linearly reduces the vasoconstriction and shivering thresholds. Anesthesiology 1995; 82: 11691180

[19] Birch DW, Dang JT, Switzer NJ et al. Heated insufflation with or without humidification for laparoscopic abdominal surgery. Cochrane Database Syst Rev 2016. doi:10.1002/14651858.CD007821.pub3

[20] Dean M, Ramsay R, Heriot A et al. Warmed, humidified $\mathrm{CO}_{2}$ insufflation benefits intraoperative core temperature during laparoscopic surgery: A meta-analysis. Asian J Endosc Surg 2017; 10: 128-136 